\title{
Selection of corn cultivars for yield, stability, and adaptability in the state of Amazonas, Brazil
}

\author{
Inocencio Junior de Oliveira(1), André Luiz Atroch(1), Miguel Costa Dias ${ }^{(1)}$, \\ Lauro José Guimarães ${ }^{(2)}$ and Paulo Evaristo de Oliveira Guimarães ${ }^{(2)}$
}

\begin{abstract}
(1)Embrapa Amazônia Ocidental, Rodovia AM-010, Km 29, Zona Rural, CEP 69010-970 Manaus, AM, Brazil. E-mail: inocencio.oliveira@embrapa.br, andre.atroch@embrapa.br, miguel.dias@embrapa.br (2)Embrapa Milho e Sorgo, Rodovia MG-424, Km 45, CEP 35701-970 Sete Lagoas, MG, Brazil. E-mail: lauro.guimaraes@embrapa.br, paulo.guimaraes@embrapa.br
\end{abstract}

\begin{abstract}
The objective of this work was to evaluate corn cultivars grown in the state of Amazonas, Brazil, which simultaneously show high grain yield, adaptability, and stability. The trials were carried out in seven environments in the state of Amazonas, in a randomized complete block design, with two replicates. The grain yield of 30 corn cultivars was evaluated in four growing seasons, from 2011/2012 to 2014/2015. The genetic parameters were estimated by the REML/Blup methodology. The selection for adaptability and stability was based on the predicted genetic value and on the harmonic mean of the relative performance of the genetic values. Despite the existence of genotype $\mathrm{x}$ environment interaction, cultivars with high adaptability and stability were identified. Iranduba - lowland, in 2011/2012 and 2014/2015 - and Rio Preto da Eva - upland, in 2012/2013 - stood out as favorable environments, while Iranduba - upland, in 2011/2012 and 2012/2013 - and Manaus - upland, in 2012/2013 and 2013/2014 - were classified as unfavorable environments. The single-cross hybrid BRS 1055 showed productive superiority and high stability in this region. The Sint 10771, Sint 10781, and Sint 10699 synthetic varieties showed high adaptability. BRS Caimbé shows specific adaptability to cropping in upland environments of the state of Amazonas, Brazil.
\end{abstract}

Index terms: Zea mays, genotype x environment interaction, REML/Blup.

\section{Seleção de cultivares de milho quanto à produtividade, estabilidade e adaptabilidade no Amazonas}

\begin{abstract}
Resumo - O objetivo deste trabalho foi avaliar cultivares de milho, cultivadas no Estado do Amazonas, que reúnam simultaneamente alta produtividade de grãos, adaptabilidade e estabilidade. Os ensaios foram conduzidos em sete ambientes do Amazonas, em delineamento de blocos ao acaso, com duas repetições. A produtividade de grãos de 30 cultivares de milho foi avaliada em quatro safras agrícolas, de 2011/2012 a 2014/2015. Os parâmetros genéticos foram estimados pela metodologia REML/Blup. A seleção quanto à adaptabilidade e à estabilidade baseou-se no valor genético predito e na média harmônica do desempenho relativo dos valores genéticos. Apesar da existência de interação genótipo x ambiente, identificaram-se cultivares com elevadas adaptabilidade e estabilidade. Os ambientes Iranduba - várzea, em 2011/2012 e 2014/2015 - e Rio Preto da Eva - terra firme, em 2012/2013 - destacaram-se como favoráveis, enquanto os ambientes Iranduba - terra firme, em 2011/2012 e 2012/2013 - e Manaus - terra firme, em 2012/2013 e 2013/2014 - foram classificados como desfavoráveis. O híbrido simples BRS 1055 apresentou superioridade produtiva e alta estabilidade nessa região. As variedades sintéticas Sint 10771, Sint 10781 e Sint 10699 apresentaram elevada adaptabilidade. BRS Caimbé apresenta adaptabilidade específica para cultivo em ambientes de terra firme do Estado do Amazonas.
\end{abstract}

Termos para indexação: Zea mays, interação genótipo x ambiente, REML/Blup.

\section{Introduction}

In the state of Amazonas, Brazil, corn (Zea mays L.) can be grown in basically two production ecosystems: dryland and wetland. Ecosystem production in dryland is characterized by not being floodable, with the possibility of cultivation during the whole year, and by the low natural fertility of the soil. In wetland, it is characterized by periodic flooding and the high natural fertility of the soil, due to the sedimentation of minerals that occurs during the flood periods.

Corn productivity in the state of Amazonas is 2,515 $\mathrm{kg} \mathrm{ha}^{-1}$ (Acompanhamento..., 2016). Considered low, it is attributed to low-tech agriculture and to the use of 
open-pollinated varieties, which allows the farmer to use the seeds in the following year or to acquire them at a low cost. However, some farmers grow hybrids that show higher productivity, but demand more technology and whose seeds are more expensive. Therefore, it is interesting for the Amazon farmer to have the option of acquiring seeds of varieties or productive hybrids with high adaptability and stability, according to each technological level.

In genetic breeding programs, the evaluation of the interaction of genotypes with environments $(\mathrm{GxE})$ is of great importance, since, in the case of this interaction, the best genotype in a given environment may not be the best one in another environment. This fact affects the profit with selection and makes it difficult to recommend cultivars with wide adaptability and stability.

Several methods for adaptability and stability analyses have been proposed (Cruz et al., 2014). Therefore, measures that incorporate, in a single statistics, adaptability and stability and average grain yield have been used, as in the works of Lin \& Binns (1988) and Annicchiarico (1992). These procedures, however, presuppose the fixed effects of genotypes, which is limiting for the analysis of unbalanced experiments (Resende, 2007). In contrast, in mixed models, for which the effects of genetic treatments are considered as random, these effects can be predicted without being affected by the effects of the fixed model, using the best linear unbiased predictor (Henderson, 1975).

This methodology, based on the mixed model equations - residual or restricted maximum likelihood/best linear unbiased prediction (REML/ Blup) -, is supported by the principle that the lower the standard deviation of the behavior of the genotype between sites, the higher the harmonic mean of the genotypic values between sites. This way, selection using the highest values of the harmonic mean of the genotypic values (MHVG) simultaneously determines selection for productivity and stability (Resende, 2002). Adaptability, in this case, refers to the relative performance associated with the genotypic values (PRVG) between environments. The predicted genotypic values (or original data) are, then, expressed as a ratio of the overall mean of each site, and, subsequently, the mean value of the proportion between sites is obtained. Therefore, the simultaneous selection for average productivity, stability, and adaptability can be performed by the method of the harmonic mean of the relative performance of the predicted genotypic values (MHPRVG).

The REML/Blup method for this kind of estimate in the corn crop has been efficiently used in the selection of promising cultivars (Arnhold et al., 2012; Fritsche-Neto et al., 2012; Mendes et al., 2012). In addition, studies developed by Arnhold et al. (2012) and Silva et al. (2014) show the importance of studying the GxE interaction in the corn-growing regions in Brazil, due to the great diversity of edaphoclimatic conditions in the country, as well as to the diversity of corn cultivars available in the market.

The objective of this work was to evaluate corn cultivars grown in the state of Amazonas, Brazil, which simultaneously show high grain yield, adaptability, and stability.

\section{Materials and Methods}

Corn yield data from the corn breeding program of Embrapa Milho e Sorgo were used for the evaluation of corn cultivars in the growing seasons from 2011/2012 to $2014 / 2015$, in seven environments, in the state of Amazonas, Brazil.

The seven experimental environments consisted of a combination of site and year, in different edaphoclimatic conditions of the state, as follows: Iranduba in a wetland ecosystem, harvest 2011/2012; Iranduba, in a dryland ecosystem, harvest 2011/2012; Iranduba, in dryland, harvest 2012/2013; Manaus, in dryland, harvest 2012/2013; Rio Preto da Eva, in dryland, harvest 2012/2013; Manaus, in dryland, harvest 2013/2014; and Iranduba, in wetland, harvest 2014/2015.

A group of 30 corn cultivars was evaluated, composed by the BRS 1055 simple hybrid, the BRS 2020 double hybrid, 12 commercial varieties - AL Avaré, CMS EAO 2008, BRS Caimbé, BRS 4103, BRS Sol da Manhã, BR 106, DSS-0402, DSS-0404, MC 20, PC 0402, VSL BS 42 C 60, and Eldorado -, besides 16 synthetic varieties in development by the breeding program - Sint Mult. TL, Synthetic 1X, Sint RxS Spod, Synthetic 256 L, Sint Pro Vit A, Sint 10697, Sint 10699, Sint 10707, Sint 10717, Sint 10723, Sint 10731, Sint 10771, Sint 10781, Sint 10783, Sint 10795, and Sint 10805. The commercial varieties AL Alvaré, 
BRS 2020, CMS EAO 2008, DSS-0402, DSS-0404, Eldorado, MC 20, and PC 0402 were not cultivated in environments 6 and 7.

In all trials, the used experimental design was randomized complete blocks with 30 cultivars and two replicates. Each plot was organized in two plant rows with $4 \mathrm{~m}$ of length and spaced $0.8 \mathrm{~m}$ apart, with $0.2 \mathrm{~m}$ between plants.

The trials in the wetland areas were sown in October, on solid ground. Sowing was carried out in November and December, and the harvest of all trials was done around 120 days after sowing. Fertilization at sowing was performed according to the results of the soil analysis in each experimental area. Crop handling consisted of the following applications: atrazine herbicide + S-metolachlor, $4.0 \mathrm{~L} \mathrm{ha}^{-1}$ of the commercial product, in pre-emergence; deltamethrin insecticide, $5 \mathrm{~g} \mathrm{ha}^{-1}$ of the active principle to control the army worm; and $100 \mathrm{~kg} \mathrm{ha}^{-1} \mathrm{~N}$ for topdressing fertilization, using half of the dose when the corn had four unfolded leaves, and the other half when it had seven unfolded leaves. The variable evaluated was grain yield $\left(\mathrm{kg} \mathrm{ha}^{-1}\right)$, corrected to $13 \%$ humidity.

To evaluate the effect of the GxE interaction, the following model was used: $\mathrm{y}=\mathrm{Xb}+\mathrm{Zg}+\mathrm{Wc}+\varepsilon$, in which $\mathrm{y}, \mathrm{b}, \mathrm{g}, \mathrm{c}$, and $\varepsilon$ correspond, respectively, to the vectors of the data of fixed block effects (averages of blocks between the environments), of the random effects of the cultivars, of the random effects of the GxE interaction, and of random errors; and X, Z, and W are the incidence matrices for $\mathrm{b}, \mathrm{g}$, and $\mathrm{c}$, respectively (Resende, 2007).

Through this model, the Blup (REML/Blup) predictors of the genotypic values free of the GxE interaction were obtained, given by $\hat{\mu}+\widehat{g}_{i}$, in which: $\mu$ is the average of all environments and, ${ }^{\widehat{\infty}} \widehat{\mathrm{g}}_{\mathrm{i}}$ is the prediction of the genotypic effect. For each $\mathrm{j}$ environment, the genotypic values $(\mathrm{Vg})$ are predicted by $\widehat{\mu}_{\mathrm{j}}+\widehat{\mathrm{g}}_{\mathrm{i}}+(\mathrm{g} \mathrm{e})_{\mathrm{ij}}$, in which: $\mu_{\mathrm{j}}$ is the average of the $j$ environment; $\hat{g}_{i}$ is the effect of the $i$ genotype, in the $\mathrm{j}$ environment; and ( $(\mathrm{ge})_{\mathrm{ij}}$ is the effect of the $\mathrm{GxE}$ interaction relative to the $i$ genotype.

The prediction of the genotypic values, which reunites the average interaction (gem) in the different environments, is given by $\widehat{\mu}_{\mathrm{j}}+\widehat{\mathrm{g}}_{\mathrm{i}}+(\mathrm{ge})_{\mathrm{m}}$ and calculated by $\hat{\mu}+\left\{\left[\left(\hat{\sigma}_{\mathrm{g}}^{2}+\widehat{\sigma}_{\mathrm{c}}^{2}\right) / \mathrm{n}\right] \hat{\sigma}_{\mathrm{g}}^{2}\right\} \hat{\mathrm{g}}_{\mathrm{i}}$, in which $\mu$ is the overall average of all environments; $n$ is the number of environments; and $\widehat{g}_{i}$ is the specific genotypic effect (i genotype).

Joint selection, which considers the average yield, stability, and adaptability of the corn cultivars, is determined by the MHPRVG, according to

$$
\operatorname{MHPRVG}_{\mathrm{i}}=\mathrm{n} /\left(\sum_{\mathrm{j}=1}^{\mathrm{n}} 1 / \mathrm{Vg}_{\mathrm{ij}}\right),
$$

in which: $\mathrm{n}$ is the number of sites where the i genotype was evaluated; and $\mathrm{Vg}_{\mathrm{ij}}$ is the genotypic value of the $\mathrm{i}$ genotype, in the $\mathrm{j}$ environment, expressed as a proportion of the average in this environment. To facilitate the interpretation, the MHPRVG values were multiplied by the overall average of all environments (MG), which results in the same order of magnitude of the studied trait.

The environments were classified as favorable and unfavorable, according to the overall average, performing MHPRVG analyses separately for each environment class, as in Mendes et al. (2012). To evaluate the capacity for adaptability, which considers stability and productivity, the MHPRVGxMG results were compared in a dispersion graph, to contrast favorable and unfavorable environments. The results of the favorable environments were plotted on the abscissa, and of the unfavorable ones on the ordinate axis. This way, the Cartesian plane was divided into four quadrants, in which the bottom left quadrant represents the cultivars with the worst performance in both groups of environments, with lack of adaptability and low productive stability; while the cultivars in the top right quadrant present superior performance in both environment classes, which is an indicative of adaptation to these environments and of high stability. The cultivars grouped at the bottom right quadrant show specific adaptability to the favorable environments, and those plotted on the top left quadrant have specific adaptability to the unfavorable environments.

\section{Results and Discussion}

The overall average of the corn cultivars, evaluated in the seven environments, in the state of Amazonas, was $4,342.6 \mathrm{~kg} \mathrm{ha}^{-1}$ (Table 1), a value greater than the state average of 2,515 kg ha-1 (Acompanhamento..., 2016). Genotypic effects and the GxE interaction were observed, according to the likelihood test, which is indicative of variability among cultivars regarding 
grain yield and their differential behavior due to environmental variations.

The high accuracy and the values of the genetic coefficients and of the coefficients of residual variation that were observed are indicative of good experimental quality (Table 1). This shows relative ease in the selection of superior cultivars, as reported by Mendes et al. (2012) and Silva et al. (2014), when evaluating the adaptability and stability of corn hybrids in Brazil. The heritability based on the averages of the genotypes $\left(\mathrm{h}_{\mathrm{m}}^{2}\right)$ was of 0.70 , which indicates a trustworthy selection of the corn cultivars, based on the predicted genotypic values.

Despite this trustworthiness, the measure of a character in the field trials refers to its phenotypic value, constituted by the genetic effect, environment effect, and the interaction of this genotype in a specific environment, that is, the sum of the genotypic and residual variances between plots and of the GxE interaction results in the individual phenotypic variance (Torres et al., 2015). Therefore, the coefficient of determination $\left(\mathrm{R}_{\mathrm{GxE}}^{2}=0.51\right)$ confirmed the large

Table 1. Overall mean, genetic parameters, estimates of the variance components and likelihood ratio test (LRT) regarding grain yield (GY) in corn (Zea mays) cultivars evaluated in seven environments in the state of Amazonas, Brazil, between the 2011/2012 and 2014/2015 harvests.

\begin{tabular}{|c|c|}
\hline \multicolumn{2}{|c|}{ Genetic parameters and variance components (individual REML) } \\
\hline $\mathrm{V}_{\mathrm{G}}$, genotypic variation & $143,259.61$ \\
\hline $\mathrm{V}_{\mathrm{GxE}}$, variation of the genotype $\mathrm{x}$ environment interaction & $319,088.06$ \\
\hline $\mathrm{V}_{\mathrm{e}}$, residual variation & $156,898.68$ \\
\hline $\mathrm{V}_{\mathrm{F}}$, individual phenotypic variation & $619,236.35$ \\
\hline $\mathrm{h}^{2}$, broad-sense heritability & $0.23 \pm 0.07$ \\
\hline $\mathrm{h}_{\mathrm{m}}^{2}$, average heritability & 0.70 \\
\hline$r_{g}$, accuracy of genotype selection & 0.84 \\
\hline $\begin{array}{l}\mathrm{R}^{2}{ }_{\mathrm{GxE}} \text {, coefficient of determination of the effects of the } \\
\text { genotype } \mathrm{x} \text { environment interaction }\end{array}$ & 0.51 \\
\hline $\begin{array}{l}r_{g(L)} \text {, genotypic correlation between performance in the } \\
\text { various environments }\end{array}$ & 0.31 \\
\hline $\mathrm{CV}_{\mathrm{g}}(\%)$, coefficient of genotypic variation & 8.72 \\
\hline $\mathrm{CV}_{\mathrm{e}}(\%)$, coefficient of residual variation & 9.12 \\
\hline Overall average $\left(\mathrm{kg} \mathrm{ha}^{-1}\right)$ & $4,342.6$ \\
\hline \multicolumn{2}{|l|}{ Likelihood ratio test (LRT) } \\
\hline Effect $^{(1)}$ & GY $\left(\mathrm{kg} \mathrm{ha}^{-1}\right)$ \\
\hline Genotype & $106.06^{* *}$ \\
\hline Genotype $\mathrm{x}$ environment & $109.00 * *$ \\
\hline
\end{tabular}

participation of the GxE interaction in the phenotypic variance of the genotypes (Table 1). This fact was also shown by the median genotypic correlation between the performances in the various environments $\left(r_{g(L)}=0.31\right)$, which results in the complex part of the GxE interaction and causes certain difficulty in the selection of genotypes with a more ample adaptation, as also noted by Arnhold et al. (2012) and Mendes et al. (2012), in a study on the genotype $\mathrm{x}$ environment interaction in corn.

The BRS 1055 simple hybrid had the highest genotypic value, the highest free average of the interaction, and the highest overall average (Table 2), which, summed to the effect of the average interaction, shows the superiority in productivity of the simple hybrids, in comparison with the varieties. The productive superiority of the hybrids, in relation to the open-pollination varieties, was also observed by Cardoso et al. (2009). In the present study, the Sint 10771, Sint 10781, and Sint 10699 varieties stood out due to genotypic values and the overall average, summed to the average interaction effect, which were superior to those of the remaining commercialized varieties and to those of the BRS 2020 double hybrid, which is indicative that these corn varieties have superior productive potential for the edaphoclimatic conditions of the state of Amazonas.

Although the BRS 1055 simple hybrid outperforms the other cultivars, it requires greater investment. Despite this, it is still a cropping alternative with high yield for less technicized areas, since its seeds are cheaper than those of other hybrids, allowing the storage and re-sowing of the harvested seeds and avoiding the annual purchase of seeds.

The average genetic gain, obtained with the selection of $20 \%$ of the evaluated cultivars (corresponding to the six superior cultivars), was above $10 \%$, highlighting the BRS 1055 hybrid and the Sint 10771 variety (Table 2). According to Pimentel et al. (2014), the genetic gain is predicted from the average genetic value of the populations and from the average genetic value of the selected individuals; the latter represents the sum of the average additive effect of the selected individuals and the average genetic value of the populations, and, for a considerable genetic gain, the genotype with a high average and ample variability should be selected.

There was an agreement in the classification of most genotypes, based on MHVG, PRVG, MHPRVG, 
and average yield (Table 3). From these results, it can be inferred that the predictions about the genotypic values can be made based only on a standard yield that includes stability and adaptability (Verardi et al., 2009). The simultaneous selection regarding yield, stability, and adaptability, using mixed models through the MHPRVG method, is adequate for use in corn breeding programs, as shown by Mendes et al. (2012).

The superior genotypes (BRS 1055, Sint 10771, Sint 10781, and Sint 10699) by the criteria of genetic averages free of the GxE interaction were also superior by the MHPRCG method (Table 3). This is indicative that these cultivars presented higher adaptability to the evaluated environments, besides good predictability, as also found by Maia et al. (2009). These results corroborate those of Mendes et al. (2012), who verified that the same order of corn genotypes was maintained by these methods.

The MHPRVG method was applied separately for the classes of favorable and unfavorable environments, according to local grain yield. In this case, environments with productivity above the overall average $(4,342.6$ $\mathrm{kg} \mathrm{ha}^{-1}$ ) were classified as favorable, and those with productivity below the overall average, as unfavorable. Mendes et al. (2012) evaluated the adaptability and stability of corn in favorable and unfavorable environments, and showed that this classification is important in the selection of genotypes with specific adaptability to the environments.

Of the seven environments evaluated, three $(1,7$, and 5) were classified as favorable, and four (3, 2, 4, and 6) as unfavorable (Table 4). The unfavorable

Table 2. Estimates of the components of grain yield averages of corn (Zea mays) cultivars, in seven environments, in the state of Amazonas, Brazil, between the 2011/2012 and 2014/2015 harvests.

\begin{tabular}{|c|c|c|c|c|c|}
\hline Genotype & Genotypic effect & $(\widehat{\mu}+\widehat{g})$ & Genetic gain $(\%)$ & Average $\left(\mathrm{kg} \mathrm{ha}^{-1}\right)$ & $(\widehat{\mu}+\widehat{g}+\widehat{g e m})$ \\
\hline BRS 1055 & 919.02 & $5,261.66$ & 21.16 & $5,261.66$ & $5,554.10$ \\
\hline Sint 10771 & 476.52 & $4,819.16$ & 16.07 & $5,040.41$ & $4,970.79$ \\
\hline Sint 10781 & 412.79 & $4,755.42$ & 13.88 & $4,945.41$ & $4,886.78$ \\
\hline Sint 10699 & 353.20 & $4,695.83$ & 12.44 & $4,883.02$ & $4,808.23$ \\
\hline AL Avaré & 267.00 & $4,609.63$ & 11.18 & $4,828.34$ & $4,694.60$ \\
\hline CMS EAO 2008 & 256.90 & $4,599.54$ & 10.31 & $4,790.21$ & $4,681.29$ \\
\hline Sint. Mult. TL & 232.94 & $4,575.58$ & 9.60 & $4,759.55$ & $4,649.71$ \\
\hline BRS Caimbé & 220.72 & $4,563.36$ & 9.04 & $4,735.02$ & $4,633.59$ \\
\hline Sint 10795 & 183.94 & $4,526.58$ & 8.50 & $4,711.86$ & $4,585.11$ \\
\hline Sint 10717 & 150.90 & $4,493.53$ & 8.00 & $4,690.03$ & 4541.55 \\
\hline BRS 2020 & 66.55 & $4,409.19$ & 7.41 & $4,664.50$ & $4,430.36$ \\
\hline Sint 10723 & 61.84 & $4,404.48$ & 6.91 & $4,642.83$ & $4,424.16$ \\
\hline DSS-0404 & 32.47 & $4,375.10$ & 6.44 & $4,622.24$ & $4,385.44$ \\
\hline MC 20 & 15.55 & $4,358.19$ & 6.00 & $4,603.38$ & $4,363.14$ \\
\hline Sint 10783 & -24.45 & $4,318.19$ & - & $4,584.36$ & $4,310.41$ \\
\hline BRS 4103 & -66.59 & $4,276.04$ & - & $4,565.09$ & $4,254.85$ \\
\hline Sint 10697 & -72.83 & $4,269.80$ & - & $4,547.72$ & $4,246.63$ \\
\hline DSS-0402 & -88.43 & $4,254.21$ & - & $4,531.42$ & $4,226.07$ \\
\hline PC 0402 & -102.45 & $4,240.19$ & - & $4,516.09$ & $4,204.58$ \\
\hline Sint 10805 & -123.57 & $4,219.06$ & - & $4,501.24$ & $4,179.74$ \\
\hline Sintético $1 \mathrm{X}$ & -163.57 & $4,179.06$ & - & $4,485.90$ & $4,127.01$ \\
\hline Eldorado & -175.70 & $4,166.94$ & - & $4,471.40$ & $4,111.03$ \\
\hline Sint RxS Spod & -230.48 & $4,112.16$ & - & $4,455.78$ & $4,038.82$ \\
\hline Sint 10707 & -235.75 & $4,106.89$ & - & $4,441.24$ & $4,031.87$ \\
\hline Sint 10731 & -236.36 & $4,106.28$ & - & $4,427.84$ & $4,031.06$ \\
\hline BR 106 & -361.27 & $3,981.37$ & - & $4,410.67$ & $3,866.40$ \\
\hline VSL BS42 C 60 & -374.58 & $3,968.06$ & - & $4,394.28$ & $3,848.87$ \\
\hline Sintético $256 \mathrm{~L}$ & -389.71 & $3,952.93$ & - & $4,378.52$ & $3,828.92$ \\
\hline Sol da Manhã & -402.45 & $3,940.19$ & - & $4,363.40$ & $3,812.13$ \\
\hline Sint. Pro Vit A & -602.14 & $3,740.50$ & - & $4,342.64$ & $3,548.89$ \\
\hline
\end{tabular}


upland environments showed, according to Fajardo et al. (2009), dystrophic or low nutrient-content soils, with $\mathrm{Al}$ saturation above $50 \%$, base saturation below $50 \%$, and contents of the $\mathrm{K}, \mathrm{Ca}$, and $\mathrm{Mg}$ bases and of $\mathrm{P}$ below the critical values used for the interpretation of soil analysis, which, together with the elevated $\mathrm{Al}$ concentration, represent one of the biggest problems for root development, negatively affecting the development of plants. Most of the favorable environments are lowland areas, with soils with high $\mathrm{Ca}, \mathrm{Mg}, \mathrm{K}, \mathrm{P}, \mathrm{Zn}$ availability and low $\mathrm{Al}$ content.

Grain yield was of 4,955.7 $\mathrm{kg} \mathrm{ha}^{-1}$, in the favorable environments, and of $3,884.1 \mathrm{~kg} \mathrm{ha}^{-1}$, in the unfavorable ones (Table 5). The favorable and unfavorable environments presented high accuracy and low value of the coefficient of residual variation; according to Pimentel et al. (2014), the higher the selective accuracy in the evaluation of an individual, the more trustworthy is the evaluation and the predicted genetic value for the individual. In addition, the average heritability above 0.70 is an indication of trustworthiness in the selection of the corn genotypes based the predicted genotypic value (Resende, 2007). It was also possible to observe a significant participation of the GxE interaction due to the high $\mathrm{R}^{2}$ values of the effects of this interaction, as well as to the median values of the genotypic correlation between the performances in the environments, both favorable and unfavorable.

The BRS 1055 simple hybrid presented the best productive and adaptability performances in the

Table 3. Stability (MHVVG), adaptability (PRVG and PRVG $\times$ MG), and stability and adaptability (MHPRVG and MHPRVG) of the genetic values of corn (Zea mays) cultivars, predicted by the best linear unbiased prediction (Blup) analysis, evaluated in the state of Amazonas, Brazil, between the 2011/2012 and 2014/2015 harvests ${ }^{(1)}$.

\begin{tabular}{|c|c|c|c|c|c|}
\hline Genotype & MHVG & PRVG & $\mathrm{PRVG} \times \mathrm{MG}$ & MHPRVG & MHPRVG×MG \\
\hline BRS 1055 & $5,529.29$ & 1.30 & $5,639.66$ & 1.28 & $5,568.32$ \\
\hline Sint 10771 & $4,871.58$ & 1.15 & $4,997.65$ & 1.14 & $4,952.12$ \\
\hline Sint 10781 & $4,758.10$ & 1.13 & $4,888.05$ & 1.12 & $4,861.17$ \\
\hline Sint 10699 & $4,708.71$ & 1.11 & $4,821.79$ & 1.11 & $4,803.55$ \\
\hline CMS EAO 2008 & $4,616.13$ & 1.09 & $4,728.27$ & 1.08 & $4,673.57$ \\
\hline BRS Caimbé & $4,539.36$ & 1.08 & $4,672.40$ & 1.06 & 4603.81 \\
\hline Sint 10795 & $4,464.12$ & 1.06 & $4,593.43$ & 1.05 & $4,, 555.18$ \\
\hline Sint. Mult. TL & $4,475.98$ & 1.08 & $4,688.68$ & 1.04 & $4,536.30$ \\
\hline AL Avaré & $4,371.46$ & 1.07 & $4,653.28$ & 1.04 & $4,510.75$ \\
\hline Sint 10717 & $4,371.44$ & 1.04 & $4,516.10$ & 1.03 & $4,484.77$ \\
\hline BRS 2020 & $4,381.85$ & 1.02 & $4,452.23$ & 1.02 & $4,431.07$ \\
\hline Sint 10723 & $4,337.98$ & 1.02 & $4,445.51$ & 1.01 & $4,415.18$ \\
\hline DSS-0404 & $4,301.65$ & 1.01 & $4,381.55$ & 1.01 & $4,367.44$ \\
\hline MC 20 & $4,315.41$ & 1.01 & $4,388.88$ & 1.00 & $4,355.45$ \\
\hline Sint 10697 & $4,149.34$ & 0.98 & $4,249.84$ & 0.98 & $4,239.55$ \\
\hline DSS-0402 & $4,191.03$ & 0.98 & $4,256.60$ & 0.97 & $4,212.02$ \\
\hline BRS 4103 & $4,105.90$ & 0.98 & $4,237.22$ & 0.97 & $4,208.79$ \\
\hline Sint 10783 & $4,095.62$ & 0.99 & $4,284.35$ & 0.97 & $4,208.76$ \\
\hline PC 0402 & $4,124.47$ & 0.97 & $4,221.61$ & 0.96 & $4,160.35$ \\
\hline Sintético $1 \mathrm{X}$ & $3,915.62$ & 0.94 & $4,087.63$ & 0.93 & $4,037.65$ \\
\hline Sint 10731 & $3,983.74$ & 0.94 & $4,076.08$ & 0.93 & $4,028.44$ \\
\hline Eldorado & $3,936.47$ & 0.93 & $4,061.71$ & 0.93 & $4,024.37$ \\
\hline Sint 10805 & $3,876.48$ & 0.95 & $4,108.90$ & 0.93 & $4,021.86$ \\
\hline Sint 10707 & $3,875.37$ & 0.93 & $4,021.87$ & 0.92 & $3,978.28$ \\
\hline Sint RxS Spod & $3,791.90$ & 0.92 & $3,994.30$ & 0.90 & $3,921.43$ \\
\hline BR 106 & $3,780.68$ & 0.89 & $3,880.80$ & 0.89 & $3,855.45$ \\
\hline Sol da Manhã & $3,706.30$ & 0.88 & $3,812.97$ & 0.87 & $3,783.68$ \\
\hline VSL BS 42 C 60 & $3,580.76$ & 0.87 & $3,801.98$ & 0.87 & $3,761.18$ \\
\hline Sintético 256 L & $3,606.20$ & 0.87 & $3,785.56$ & 0.85 & $3,714.74$ \\
\hline Sint. Pro Vit A & $3,437.92$ & 0.81 & $3,533.25$ & 0.81 & $3,528.34$ \\
\hline
\end{tabular}

(1)MHVG, harmonic mean of the genotypic values; PRVG, genotypic values; MG, overall average; and MHPRVG, harmonic mean of the relative performance of the predicted genotypic values. 
favorable and unfavorable environments, besides high productive stability (Figure 1). Mendes et al. (2012) also showed higher productive stability of hybrids compared with varieties, in 49 environments. In the present study, besides the BRS 1055 simple hybrid, the Sint 10781, Sint 10771, and Sint 10699 varieties also showed high productive performance and adaptability to the favorable and unfavorable environments, as well

Table 4. Average grain yield of corn (Zea mays) and classification of the environments evaluated in the state of Amazonas, Brazil, between the 2011/2012 and 2014/2015 harvests.

\begin{tabular}{lcc}
\hline Environment/harvest & Average $\left(\mathrm{kg} \mathrm{ha}^{-1}\right)$ & Class \\
\hline 1, Iranduba - wetland - 2011/2012 & $5,472.98$ & Favorable \\
7, Iranduba - wetland - 2014/2015 & $5,044.01$ & Favorable \\
5, RPE - dryland - 2012/2013 & $4,347.55$ & Favorable \\
3, Iranduba - dryland - 2012/2013 & $4,241.50$ & Unfavorable \\
2, Iranduba - dryland - 2011/2012 & $4,149.37$ & Unfavorable \\
4, Manaus - dryland - 2012/2013 & $3,590.67$ & Unfavorable \\
6, Manaus - dryland - 2013/2014 & $3,552.38$ & Unfavorable \\
\hline
\end{tabular}

as high productive stability, which confirms the results of the evaluation of the prediction of genotypic values

Table 5. Genetic parameters and estimates of the variance components regarding grain yield of corn (Zea mays) in favorable and unfavorable environments, in the state of Amazonas, Brazil, between the 2011/2012 and 2014/2015 harvests.

\begin{tabular}{lcc}
\hline $\begin{array}{l}\text { Genetic parameters and } \\
\text { variance components }^{(1)}\end{array}$ & $\begin{array}{c}\text { Favorable } \\
\text { environments }\end{array}$ & $\begin{array}{c}\text { Unfavorable } \\
\text { environments }\end{array}$ \\
\hline $\mathrm{V}_{\mathrm{G}}$ & $36,942.72$ & $198,094.30$ \\
$\mathrm{~V}_{\mathrm{GxE}}$ & $478,361.68$ & $226,867.04$ \\
$\mathrm{~V}_{\mathrm{e}}$ & $204,906.40$ & $122,210.08$ \\
$\mathrm{~V}_{\mathrm{F}}$ & $720,210.80$ & $547,171.42$ \\
$\mathrm{~h}^{2}{ }_{\mathrm{i}}$ & $0.35 \pm 0.05$ & $0.36 \pm 0.11$ \\
$\mathrm{~h}_{\mathrm{m}}$ & 0.75 & 0.72 \\
$\mathrm{r}_{\mathrm{g}}$ & 0.89 & 0.85 \\
$\mathrm{R}^{2}{ }_{\mathrm{GxE}}$ & 0.56 & 0.41 \\
$\mathrm{r}_{\mathrm{g}(\mathrm{L})}$ & 0.37 & 0.47 \\
$\mathrm{CV}_{\mathrm{g}}(\%)$ & 3.88 & 11.46 \\
$\mathrm{CV}_{\mathrm{e}}(\%)$ & 9.13 & 9.00 \\
\hline${\text { Overall average }\left(\mathrm{kg} \mathrm{ha}^{-1}\right)}$ & $4,955.67$ & $3,884.13$ \\
\hline
\end{tabular}

${ }^{(1)}$ Description according to Table 1.

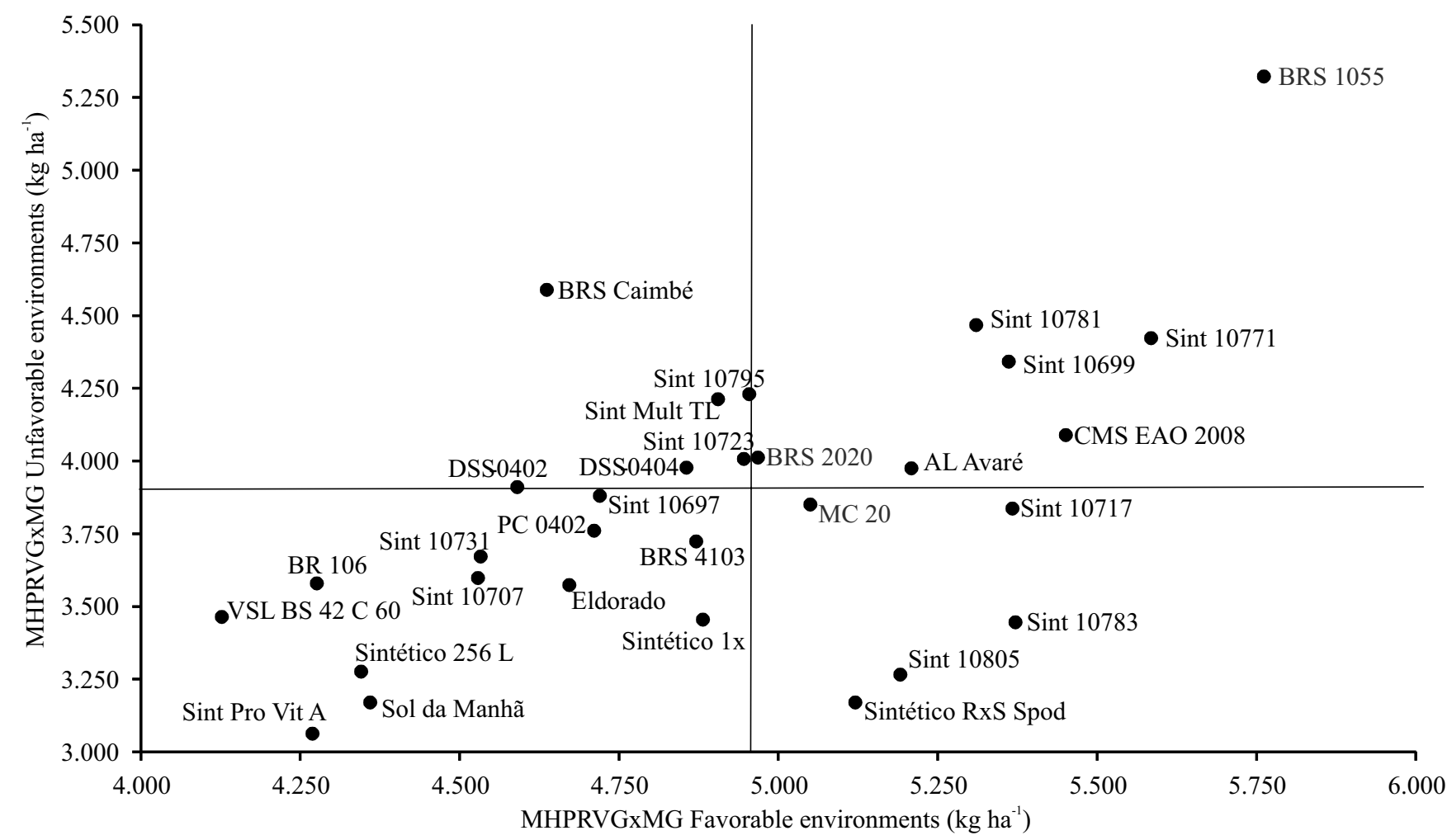

Figure 1. Dispersion plot of the MHPRVG $\times$ MG stability for grain yield of corn (Zea mays) cultivars, in favorable and unfavorable environments, in the state of Amazonas, Brazil, between the 2011/2012 and 2014/2015 harvests. MHPRVG, harmonic mean of the relative performance of the predicted genotypic values; and MG, overall average. 
(Table 2). With these results, the productive superiority of these synthetic varieties is confirmed in relation to the BR 106 and Sol da Manhã commercial varieties, which showed low productivity, lack of adaptability to both classes of environment, and little stability. Mendes et al. (2012) also observed low a productive stability of the Sol da Manhã and BR 106 varieties, in evaluations in different environmental conditions of Brazil.

The BRS Caimbé variety presented the best productive performance and specific adaptability in unfavorable environments (Figure 1), which makes it a good option for cultivation in the upland areas of the state of Amazonas.

\section{Conclusions}

1. The BRS 1055 simple corn (Zea mays) hybrid shows superior productivity and high stability.

2. The Sint 10771, Sint 10781, and Sint 10699 varieties have potential to be cultivated in the state of Amazonas, Brazil, because they combine high productivity and productive stability.

3. The BRS Caimbé variety presents specific adaptability, which makes it a cultivation option for the upland environments of the state of Amazonas.

\section{Acknowledgments}

To Empresa Brasileira de Pesquisa Agropecuária (Embrapa), for supplying the seeds; and to João Batista Sales de Sousa, for technical assistance in conducting and evaluating the field trials.

\section{References}

ACOMPANHAMENTO DA SAFRA BRASILEIRA [DE] GRÃOS: safra 2015/16: nono levantamento, v.3, n.9, jun. 2016. 169p. Available at: <http://www.conab.gov.br/OlalaCMS/uploads/ arquivos/16_06_09_09_00_00_boletim_graos_junho_2016_-final.pdf>. Accessed on: July 112016.

ANNICCHIARICO, P. Cultivar adaptation and recommendation from alfalfa trials in Northern Italy. Journal of Genetics and Plant Breeding, v.46, p.269-278, 1992.

ARNHOLD, E.; MORA, F.; PACHECO, C.A.P.; CARVALHO, H.W.L. de. Prediction of genotypic values of maize for the agricultural frontier region in northeastern Maranhão, Brazil. Crop Breeding and Applied Biotechnology, v.12, p.151-155, 2012. DOI: $10.1590 /$ S1984-70332012000200009.
CARDOSO, M.J.; CARVALHO, H.W.L. de; PACHECO, C.A.P.; OLIVEIRA, I.R. de; ROCHA, L.M.P.; TABOSA, J.N.; LIRA, M.A.; MELO, K.E. de O. Adaptabilidade e estabilidade de cultivares de milho na região Meio-Norte do Brasil na safra 2006/2007. Agrotrópica, v.21, p.173-180, 2009.

CRUZ, C.D.; CARNEIRO, P.C.S.; REGAZZI, A.J. Modelos biométricos aplicados ao melhoramento genético. 3.ed. rev. e ampl. Viçosa: Ed. da UFV, 2014. v.2, 668p.

FAJARDO, J.D.V.; SOUZA, L.A.G. de; ALFAIA, S.S. Características químicas de solos de várzeas sob diferentes sistemas de uso da terra, na calha dos rios Baixo Solimões e Médio Amazonas. Acta Amazonica, v.39, p.731-740, 2009. DOI: $10.1590 / \mathrm{S} 0044-59672009000400001$.

FRITSCHE-NETO, R.; RESENDE, M.D.V.; MIRANDA, G.V.; DOVALE, J.C. Seleção genômica ampla e novos métodos de melhoramento do milho. Revista Ceres, v.59, p.794-802, 2012. DOI: $10.1590 / \mathrm{S} 0034-737 X 2012000600009$.

HENDERSON, C.R. Best linear unbiased estimation and prediction under a selection model. Biometrics, v.31, p.423447, 1975. DOI: $10.2307 / 2529430$.

LIN, C.S.; BINNS, M.R. A superiority measure of cultivar performance for cultivar $x$ location data. Canadian Journal of Plant Science, v.68, p.193-198, 1988. DOI: 10.4141/ cjps 88018 .

MAIA, M.C.C.; RESENDE, M.D.V.; PAIVA, J.R. de; CAVALCANTI, J.J.V.; BARROS, L. de M. Seleção simultânea para produção, adaptabilidade e estabilidade genotípicas em clones de cajueiro, via modelos mistos. Pesquisa Agropecuária Tropical, v.39, p.43-50, 2009.

MENDES, F.F.; GUIMARÃES, L.J.M.; SOUZA, J.C.; GUIMARÃES, P.E.O.; PACHECO, C.A.P.; MACHADO, J.R. de A.; MEIRELLES, W.F.; SILVA, A.R. da; PARENTONI, S.N. Adaptability and stability of maize varieties using mixed model methodology. Crop Breeding and Applied Biotechnology, v.12, p.111-117, 2012. DOI: 10.1590/S198470332012000200003.

PIMENTEL, A.J.B.; GUIMARÃES, J.F.R.; SOUZA, M.A. de; RESENDE, M.D.V. de; MOURA, L.M.; ROCHA, J.R. do A.S. de C.; RIBEIRO, G. Estimação de parâmetros genéticos e predição de valor genético aditivo de trigo utilizando modelos mistos. Pesquisa Agropecuária Brasileira, v.49, p.882-890, 2014. DOI: 10.1590/S0100-204X2014001100007.

RESENDE, M.D.V. de. Genética biométrica e estatística no melhoramento de plantas perenes. Brasília: Embrapa Informação Tecnológica; Colombo: Embrapa Florestas, 2002. 975p.

RESENDE, M.D.V. de. Matemática e estatística na análise de experimentos e no melhoramento genético. Colombo: Embrapa Florestas, 2007. 561p.

SILVA, P.R. da; BISOGNIN, D.A.; LOCATELLI, A.B.; STORCK, L. Adaptability and stability of corn hybrids grown for high grain yield. Acta Scientiarum. Agronomy, v.36, p.175-181, 2014. DOI: 10.4025/actasciagron.v36i2.17374. 
TORRES, F.E.; TEODORO, P.E.; SAGRILO, E.; CECCON, G.; CORREA, A.M. Interação genótipo $\mathrm{x}$ ambiente em genótipos de feijão-caupi semiprostrado via modelos mistos. Bragantia, v.74, p.255-260, 2015. DOI: 10.1590/16784499.0099.
VERARDI, C.K.; RESENDE, M.D.V. de; COSTA, R.B. da; GONÇALVES, P. de S. Adaptabilidade e estabilidade da produção de borracha e seleção em progênies de seringueira. Pesquisa Agropecuária Brasileira, v.44, p.1277-1282, 2009. DOI: 10.1590/S0100-204X2009001000010.

Received on March 9, 2016 and accepted on August 8, 2016 